Marianne $\emptyset$ degaard er førsteamanuensis i naturfagdidaktikk ved Naturfagsenteret på Universitetet i Oslo hvor hun er forskningsleder. Hun er opptatt av naturfag som et allmenndannende fag, og hvordan blant annet drama kan bidra til dette. Hun er nå involvert i videobasert klasseromsforskning, hvor hun er spesielt interessert i læreres undervisningstilbud til elevene.

Nina E. Arnesen er ansatt på seksjon for Læring og lærerutdanning ved Universitetet for miljø- og biovitenskap. Hun er opptatt av hvordan elevene bruker samtalen i klasserommet til å konstruere sin naturfaglige forståelse, og hvordan læreren kan bidra til dette. Hun er også involvert i utviklingen av et verktøy som skal gi lærere mulighet til å bruke forskningsfunn for å reflektere over egen praksis. Arnesen har vært lærer på ungdomstrinnet i en årrekke.

MARIANNE $\varnothing D E G A A R D$

Naturfagsenteret, Universitetet i Oslo, Norge

e-post: marianne.odegaard@naturfagsenteret.no

NINA E. ARNESEN

Universitetet for miljø-og biovitenskap, Norge

e-post:n.e.arnesen@umb.no

\title{
Hva skjer i naturfagklasserommet? - resultater fra en videobasert klasseromsstudie; PISA+
}

\begin{abstract}
The aim of the PISA+ project is to pursue problematic findings in the international PISA survey. Through in-depth studies of classroom processes we wish to gain insight in how to understand and interpret the Norwegian results. The PISA+ project is a qualitative video study using observations and interviews. It includes six ninth grade classes followed for three weeks each in math, Norwegian and science. This paper focuses on the science lessons, and seeks to scrutinize which learning activities the students are offered, how the students can influence the lessons and to which extent they can learn science through own experience and talking science. We conclude that science teachers are quite open to student initiatives, and that the dominating learning activity is going through new subject matter in dialogue with the students. However, we saw very little inquiry science where students used practical experiments as a basis to actively talk science.
\end{abstract}

\section{INTRODUKSJON}

Norsk skole har fått mye kritikk etter de siste års resultater fra de store internasjonale studiene PISA, - Programme for International Student Assessment) - og TIMSS - Trends in International Mathematics and Science Study. (Lie, Kjærnsli, Roe, \& Turmo, 2001; Grønmo, Bergem, Kjærnsli, Lie, \& Turmo, 2004; Kjærnsli, Lie, Olsen, Roe, \& Turmo, 2004; Kjærnsli, Lie, Olsen, \& Roe, 2007). Elevene skåret lavere enn gjennomsnittet for OECD landene i PISA, og de norske resultatene er nå de svakeste i Norden i alle tre fag som testes, naturfag, matematikk og lesing. Ikke minst urovekkende er det at norske elever er blant de med størst tilbakegang i skår fra PISA 2000 og til PISA 2006. Hvorfor har vi denne tilbakegangen? Hva er årsakene til at elever presterer dårligere på en undersøkelse som måler både elevenes begrepsforståelse og elevenes evne til å forstå og tolke naturvitenskaplige prosesser? De dårlige prestasjonene er blitt debattert, og det er mange forslag til forklaringer; alt fra bråkete elever, dårlig utdannede lærere, Gudmund Hernes' grunnskolereform i 1997 og endog PISA- og TIMSS- undersøkelsene i seg selv. 
Prosjektet PISA+ (Prosjekt om Lærings- og UndervisningsStrategier i Skolen) ble etablert for å forsøke å forstå noen av de pedagogiske prosessene i norske klasserom i dag og se disse i forhold til PISA og TIMSS resultatene. Prosjektets overordnede forskningsspørsmål er:

- Hvordan kan vi forstå og fortolke det generelle prestasjonsnivået og mønstre i de norske PISA resultatene?

- Hvordan kan vi forstå de pedagogiske prosessene som former denne realiteten?

- Hvordan kan vi transformere noen av PISA-funnene til konkrete forslag for å forbedre norsk utdanning i et livslangt læringsperspektiv?

\section{FORSKNINGSSP ФRSMÅL}

Denne artikkelen vil ta for seg noen elementer av den naturfaglige delen av prosjektet. Vi ser på hvilke læringsaktiviteter elevene tilbys, og hvordan det legges til rette for at elevene skal skape mening i naturfagundervisningen. Bruk av språk i naturvitenskapelig samtale vil være fokus i en senere artikkel (Ødegaard \& Arnesen, in press).

Her er våre forskningsspørsmål for denne naturfagstudien:

- Hvilke læringsaktiviteter får elevene tilbud om i naturfagundervisningen?

- I hvilken grad er elevene med og påvirker sin egen naturfagundervisning?

- I hvilken grad tilrettelegges det for at elever skal tilegne seg naturfaglig kunnskap basert på egne erfaringer og bruk av samtale?

Vi regner ikke med å kunne gi et entydig svar på hvorfor prestasjonsnivået i naturfag har gått ned, men håper, gjennom våre resultater, å kunne gi et bilde av hvordan undervisningen framstår og diskutere dette mot nyere naturfagdidaktisk litteratur og innføring av nyere arbeidsformer i skolen. Vi håper således på å bidra til en økt informert debatt om norsk naturfagundervisning.

\section{PISA+}

PISA+ er et videobasert forskningsprosjekt fra seks ulike klasserom i niende klassetrinn ved seks ulike skoler. Prosjektet omfatter matematikk, lesing og naturfag. Det er en kvalitativ dybdestudie som undersøker de pedagogiske prosessene bak resultatene fra tidligere PISA-studier (Kjærnsli et al. 2004; Lie et al. 2001) og evalueringsstudier av norske skoler (Klette, 2003; Schmidt, et al., 1996). Metodologien er inspirert av Evaluering av Reform 97 (Klette, 2003) og det internasjonale The Learner's Perspective Study (Clarke, 2002). Forhåpentligvis vil PISA+' resultater kunne tilby ny kunnskap som kan anvendes til å forbedre læring i skolen.

PISA+ fokuserer på å studere tilbudte læringsaktiviteter (handlinger) og erfarte læringsaktiviteter (mening). Derfor er prosjektet utformet som en videostudie med observasjoner og intervjuer av lærere og elever. Videoformatet gjør det mulig for oss å sammenlikne organiserende strukturer, aktiviteter og oppgaver i konkrete situasjoner på tvers av fag og klasserom. Gjennom intervjuene kan handlinger og meningskonstruksjon kommenteres. På denne måten kan vi på et overordnet nivå se mønstre og konsekvenser av handlinger som skjer på et klasseromsnivå, og forsøke å forstå grunnlaget for handlingen ved å gå i dybden på enkelttimer.

\section{BAKGRUNN FOR PISA+ NATURFAG}

PISA+ tar utgangspunkt i resultater fra flere ulike studier. Disse har vært viktige for utformingen av prosjektet, hvilket datamateriale vi har valgt å fokusere på, og tolkning av resultater. PISA og TIMSS er begge store, internasjonale undersøkelser med kvantitative, komparative data. Evaluering av Reform 97 (Klette, 2003) og den internasjonale klasseromsstudien igangsatt i tilknytning til TIMSS 1995, The Survey of Mathematics and Science Opportunities study (SMSO) (Schmidt et al., 1996) er begge kvalitative klasseromsstudier, designet for å kunne si noe om typiske trekk ved blant annet norsk klasseromsundervisning. 
Da PISA+ samlet inn sitt datamateriale, var læreplanen fra 1997 (L97) gjeldende. En av de rådende målsettingene med denne læreplanen var individuelt tilpasset opplæring, og læringssynet var i hovedsak konstruktivistisk: "Elever bygger i stor grad selv opp sin kunnskap, opparbeider sine ferdigheter og utvikler sine holdninger." (Kirke-, utdannings- og forskningsdepartementet (KUF) 1996, s.28). Når det gjelder naturfag, foreslår læreplanen at faget skal tilrettelegge for mange ulike aktiviteter, inkludert å sanse, observere, sortere, gjøre forsøk og gjøre feltarbeid (KUF. 1996).

\section{PISA og TIMSS}

PISA 2003 og 2006 viste at innen alle tre disipliner (lesing, matematikk og naturfag) presterte norske elever under OECD-gjennomsnittet, og dårligere enn i 2000 (Kjærnsli et al., 2004; Kjærnsli et al., 2007). Særlig har tilbakegangen vært stor i naturfag. Kjønnsforskjellene i lesing er blitt større i jentenes favør. I tillegg rapporterte elevene i PISA2000 om et svakt repertoar av læringsstrategier, svakt læringstrykk og høyt nivå av bråk og uro.

Også i TIMSS 2003 viste norske elever en markant tilbakegang i skåre fra forrige undersøkelse, som var i 1995 (Grønmo et al., 2004). De skåret riktignok litt over det internasjonale gjennomsnittet, men klart lavere enn land det er naturlig å sammenlikne seg med som Sverige, Nederland og USA. Over $70 \%$ av de norske elevene skåret på nivå 1 (lavt) eller 2 (middels), hvor nivå 4 er mest avansert. I TIMSS 2007 fortsetter tilbakegangen svakt for elever på åttende trinn i naturfag (Grønmo \& Onstad, 2008).

PISA-rapportene (Kjærnsli et al., 2004; Kjærnsli et al., 2007) og TIMSS-rapporten (Grønmo et al., 2004) antyder endrede lærer- og elevroller som en av flere mulige årsaker til elevers nedgang i resultater. Elever har fått større innflytelse gjennom økt elevmedvirkning, og man stiller dermed større krav til elevers selvregulerte læring. Man peker også på økt betoning av "ansvar for egen læring” og dermed økt bruk av elevsentrerte undervisningsformer som tverrfaglig prosjektarbeid og arbeidsplaner med selvstendig arbeid med oppgaver. Dette har igjen ført til endring av lærerrollen fra formidler til veileder. Lærere synes også å opptre med mindre autoritet. Det pekes på at læringsmålene i L97 inneholder en mengde formuleringer om hva elevene skal gjøre, men lite konkret om hva elevene skal oppnå ved aktiviteten, og at man undres på om elevaktivitetene knyttes til læring av fagstoff.

I TIMSS-undersøkelsen ble lærere spurt om bruk av arbeidsmetoder i naturfagundervisningen. At elevene følger med når lærer gjennomgår faglig stoff rapporteres som den hyppigst brukte aktiviteten. Dernest jobber elevene med oppgaver enten på egen hånd eller under veiledning av lærer. Norske elever arbeider imidlertid relativt sett oftere med oppgaver på egen hånd enn andre land, og lekser i naturfag følges i liten grad opp av lærerne i Norge. Eksperimentell undervisning derimot, meddeles å være mindre vanlig i Norge enn gjennomsnittet internasjonalt (Grønmo et al., 2004). Dette gjelder også for TIMSS 2007 (Grønmo \& Onstad, 2008).

Både PISA- og TIMSS-rapportene legger vekt på at det ikke er hvilken undervisningsform som blir brukt som er viktig, men hvilken fagdidaktisk kvalitet den er preget av, for eksempel hvordan aktivitetene integreres i undervisningen og hvilken refleksjon hos elevene læreren legger opp til.

\section{Evaluering av Reform 97 og SMSO}

Evaluering av Reform 97 (Klette, 2003) er som navnet sier en evalueringsstudie av innføringen av den forrige læreplanen, Reform 97 (KUF, 1996). Et av delstudiene var å undersøke dominerende arbeids- og samhandlingsformer i norske klasserom. Studien er tverrfaglig, og vi kan derfor ikke lese ut av den hva som er spesielt for naturfag, men felles for fag på ungdomstrinnet er at det er lite variert arbeids- og organiseringsmønster. Den dominerende arbeidsformen er helklasseundervisning hvor lærer formidler fagstoff, dernest individuelt arbeid med oppgaver. Dette stemmer overens med det lærere og elever rapporterte i TIMSS 2003 og 2007. Interaksjonen mellom lærere og 
elever er preget av respekt og toleranse og med stor vilje til å se enkeltindividet. Klette viser til at det brukes lite tid til avrunding og oppsummering, og at de ulike aktivitetenes intensjoner derved blir uklar for elevene, noe som igjen fører til en svak sammenheng mellom "å gjøre noe og å lære noe". Hun har inntrykk av at det er "lite systematisk og oppsummert refleksjon rundt de ulike aktivitetenes læringspotensiale" (Klette, 2003, s.72). De ulike aktivitetene blir ofte gjennomført uten at de blir satt inn $\mathrm{i}$ en helhetlig faglig sammenheng.

SMSO-studien er en internasjonal klasseromsstudie som sammenlikner pedagogisk flyt i klasserom på tvers av land. Begrepet "pedagogisk flyt" viser til at naturfagtimer og andre timer har visse karakteristiske trekk og mønstre som er nedfelt i tradisjoner og kultur i et land, snarere enn bevisste pedagogiske valg. SMSO-forskerne skapte begrepet "karakteristisk pedagogisk flyt", som fokuserer på utførte pedagogiske strategier, jakten på det typiske og karakteristiske for et land og en erkjennelse av at faktiske klasseromssamhandlinger er mer intuitive enn analytiske for erfarne lærere. Mange valg er bygget på rutiner, erfaringer og antagelser. SMSO karakteriserte den pedagogiske flyten i seks land, inkludert Norge (Schmidt et al., 1996), og den gir viktig informasjon angående hvordan den pedagogiske flyten var i norske naturfagtimer for vel ti år siden. Typiske trekk var at man la vekt på elevenes akkumulasjon av korrekte faktakunnskaper og elevenes engasjement i øvelser, læringsaktiviteter og klasseromssamtaler. Det ble forventet at elevene forsto fakta gjennom å gjøre praktiske aktiviteter. Innholdet i timene var vanligvis lettfattelig, og ofte dreiet det seg om definisjoner eller beskrivelser av enkle begreper. Det var lite diskusjon i klassene om fagstoff. Lærernes spørsmål omhandlet oftere prosedyrer enn det substansielle innholdet. Timene var gjerne todelt på den måten at man begynte med en introduksjon til nytt stoff eller oppfølging av stoff fra forrige gang, og siden jobbet elevene uavhengig med øvelser, oppgaver eller utforskende oppgaver. Lærerne oppsummerte sjeldent resultater eller kunnskaper tilegnet i løpet av timen. SMSO viser til at elevsentrert undervisning kan føre til uklar framdrift og mål for undervisningen.

\section{MeningsSKapende NATURFAGUNDERVISNING}

Vårt syn på læring av naturfag er basert på Vygotsky's perspektiv som hevder at læring oppstår i sosiale situasjoner, og at internaliseringsprosessen går fra sosiale kontekster til individuell forståelse (Vygotsky, 1978; 1986). Dette synspunktet, at de sosiale prosessene er vesentlig for læring, er allment akseptert på den naturfagdidaktiske arena (se Leach \& Scott, 2003; Mortimer \& Scott, 2003; Lemke, 2001; Carlsen, 2007; Wellington \& Osborne, 2001). Man tenker seg at man møter nye ideer og begreper i sosiale situasjoner og at disse blir prøvet ut i samhandling med andre ved en rekke kommunikasjonsformer som tale, fakter, skriving, visuelle bilder og handling. En viktig del av den sosiale utprøvingen av ideer og begreper innebærer å sammenlikne egne forestillinger med andres forestillinger i tillegg til naturvitenskapens forklaringer (Scott, Asoko \& Leach, 2007). Deltakerne reflekterer over og gjør seg opp en mening om hva som blir kommunisert i situasjonen. Mortimer og Scott (2003) beskriver for eksempel læring som både individuell meningsskaping hvor man rekonstruerer gamle og nye ideer, og dialogisk meningsskaping hvor ideer gis et språk i en sosial sammenheng. Her skapes mening ved at man får forståelse av faglig kunnskap; i første rekke begrepsforståelse. Vi har tatt utgangspunkt i arbeidene til Lemke (1990) og Mortimer og Scott (2003) når vi har laget vårt kategoriseringssystem for analyse av video fra våre naturfagklasserom.

Praktisk arbeid i naturfagundervisningen har vært i fokus lenge (Almendingen, Klepaker, \& Tveita, 2003; Anderson, 2007; Jenkins, 1999; Kind, Kjærnsli, Lie, \& Turmo, 1999; Klepaker, Almendingen \& Tveita, 2007; KUF, 1996), både fordi det er viktig at elevene får innblikk i prosessdimensjonen ved naturvitenskapen (Isnes, 2005; Kunnskapsdepartementet (KD), 2006; Sjøberg 2004), og fordi det beriker elevenes læring om naturvitenskapelige fenomener og systemer (Dewey, 1936; Driver 1983; Scott, Asoko \& Leach, 2007). 
I det anglo-amerikanske naturfagdidaktikkmiljøet har ideen om "inquiry-based science teaching" (undersøkelsesbasert naturfagundervisning) vært rådende. Den anses som velegnet til både å veilede og belyse elevers forståelse av naturvitenskapelige prosesser og naturvitenskapelige begreper (Keys \& Bryan 2001). Det er imidlertid ingen klar felles definisjon eller metodebeskrivelse for hva undersøkelsesbasert naturfagundervisning er. Utformingen vil nødvendigvis være avhengig av læreres tolkninger av hva undersøkelser er og andre faktorer i de lokale læringsmiljøer (ibid). Det finnes allikevel noen fellestrekk for denne type undervisning (Anderson, 2007):

- Den kjennetegnes ved at undersøkelser av autentiske spørsmål frambrakt av elevene er en sentral strategi for å undervise naturfag.

- Den refererer til elevaktiviteter hvor de kan utvikle kunnskap om og forståelse for naturvitenskapelige ideer, og likeledes en forståelse for hvordan forskere studerer naturen.

- Elevene arbeider ofte i grupper, og arbeidet de gjør kan ses på som bidrag til å løse felles problemer.

Engle og Conant (2002) har foreslått fire veiledende prinsipper for å fremme produktivt fag-engasjement. Med dette mener de at elever i samhandling med andre elever bidrar til diskusjonen om det emnet som er i fokus, gjerne gjentatte ganger med stor iver (fagengasjement), og at elevenes engasjement fører til intellektuell framgang (er produktivt). Ved å trekke inn både faglig innhold og samhandling, belyses læring samtidig som en kognitiv og sosial prosess. De fire kriteriene er;

1. å problematisere faglig innhold (lærere oppfordrer elever til å stille spørsmål, komme med kritiske kommentarer osv., i stedet for å passivt godta presenterte fakta)

2. å gi elever autoritet (gi elever mulighet til å innta en aktiv rolle ved å være en reell bidragsyter)

3. å holde elever ansvarlige overfor andre og overfor faglige standarder (elever forventes å sammenholde egne og andres oppfatninger med faglig relevante kilder)

4. å sørge for relevante undervisningsressurser (f.eks. nok tid til å gå i dybden, adgang til informasjon).

Disse fire prinsippene kan hjelpe oss å evaluere eller forstå læringsmiljøer som vil tilrettelegge for elevers produktive fagengasjement, hevder Engle og Conant (2002)

Både kjennetegnene for undersøkelsesbasert undervisning og prinsippene for produktivt fagengasjement synes å være gode kriterier for læring i naturfag som er forenelige med den rådende debatten om naturfagundervisning. Vi legger disse kriteriene til grunn for å diskutere meningsskapende naturfagundervisning i denne artikkelen.

Vi har her presentert bakgrunnen for PISA+ studien generelt og for naturfagdelen spesielt. Sammen med dette har vi presentert noen teoretiske perspektiver som bakgrunn for våre analysekategorier. Vi håper at analysekategoriene vil hjelpe oss til å karakterisere de involverte naturfagtimene $\mathrm{i}$ denne studien slik at vi kan prøve å forstå og diskutere dem i forhold til ideer om meningsskapende naturfagundervisning, for igjen å prøve å forstå bakgrunnen for resultatene fra PISA og TIMSS-undersøkelsene.

\section{DATAINNSAMLING}

Våre primære informasjonskilder er naturfagklasserom på 9.trinn. Elevene er 14-15 år gamle. Studien inkluderer 6 klasser på 6 ulike skoler. Skolene er valgt ut slik at vi får variasjon i forhold til demografi og pedagogisk organisering. To skoler ligger i urbane strøk (skole 5 og 6), to ligger i landlige strøk (skole 1 og 3 ) og to ligger i forstedsområder (skole 2 og 4). To av skolene definerte seg selv som skoler med spesiell pedagogisk organisering. I dette ligger for eksempel utstrakt bruk av tverrfaglig undervisning med temadager (skole 5) eller høyt innslag av individuelt arbeid med bruk av arbeidsplan (skole 4). Hver klasse ble observert i tre uker. Datainnsamlingsperioden dekker til sammen nesten et helt skoleår. 
I tabell 1 viser vi en oversikt over observerte/filmede økter i fagene. På skole 2, 3 og 5 filmet vi noen parallelle grupper og noen valgfrie økter med naturfaglig innhold. Derfor er det flere undervisningsøkter fra disse skolene. Ellers filmet vi alle naturfagtimer i den perioden vi var på skolen. På skole 4, hvor det var økt vekt på individuelt arbeid, var det naturlig nok færre undervisningstimer viet spesielle fag. I tillegg var naturfaglæreren syk, så en time ble avlyst. På grunn av en spesiell hendelse på skole 1, fikk vi bare observert én naturfagtime på denne skolen. Vi velger allikevel å ta den med i figurene som viser variasjon over skoler, men vi presiserer at sammenlikningsgrunnlaget med de andre skolene ikke er god.

Datamaterialet består av video, observasjoner og intervjuer. Vi har brukt tre kameraer; et fjernstyrt kamera som følger læreren, et som gir et oversiktsbilde av hele klassen og et som fokuserer på en liten gruppe elever, som regel to. I tillegg har vi gjennomført semi-strukturerte intervjuer med elever og observerte lærere, hvor informantene fikk mulighet til å kommentere videoene fra timene. Etter hver undervisningsøkt er to elever blitt intervjuet, nye elever for hver økt. Lærerne er intervjuet om en utvalgt økt i uka.

Elever og deres foresatte har gitt skriftlig samtykke til å delta i videostudien. Vi sørget for å ikke filme og intervjue de som ikke ville delta. Selv om noen av elevene tydelig gjorde seg til foran kamera, var ikke hovedinntrykket av klassene veldig forskjellig fra vanlig, opplyste lærerne oss om. Elevene bekreftet også at timene var slik de pleier å være, selv om noen hevdet at læreren kjeftet litt mindre.

For å analysere videoene har vi brukt software programmet Videograph. PISA+ prosjektet har en svært omfattende database av videomateriell (se tabell 1).

Tabell 1. Antall undervisningsøkter og antall minutter digitaliserte videoopptak av naturfagundervisning på de ulike skole.

\begin{tabular}{|c|c|c|}
\hline & \multicolumn{2}{|c|}{ Naturfag } \\
\hline Skole 1 & 1 & $42 \mathrm{~min}$ \\
\hline Skole 2 & 9 & $194 \mathrm{~min}$ \\
\hline Skole 3 & 11 & $445 \mathrm{~min}$ \\
\hline Skole 4 & 3 & $153 \mathrm{~min}$ \\
\hline Skole 5 & 16 & $677 \mathrm{~min}$ \\
\hline Skole 6 & 5 & $254 \mathrm{~min}$ \\
\hline & 45 & $1765 \mathrm{~min}$ \\
\hline
\end{tabular}

\section{ANALYSEN}

Software Videograph (Rimmele, 2002) er et program for å spille av og analysere digitaliserte videofiler. Ved hjelp av programmet kan man konstruere en visuell fargeprofil for hver økt, som synliggjør tidsbruken av de ulike aktiviteter slik disse er blitt kodet av forskerne i ettertid.

\section{Felles koding for alle fag}

De tre hovedkategoriene som ble brukt i vår fellesanalyse av alle fag, har i hovedsak fokus på læreren. De er: aktiviteter ved helklasseinstruksjon, læreraktiviteter ved individuelt arbeid og læreraktiviteter ved gruppearbeid. Kategoriene er gjensidig utelukkende. Hver kategori er igjen delt 
Tabell 2. Kodeskjema for fellesanalysen av alle tre fag (naturfag, matematikk og norsk). Klette et al., 2005

\section{Aktivitet ved helklasseinstruksjon}

\begin{tabular}{|c|c|}
\hline Instruksjon - monologisk & forelesning/fortelling/lærer leser høyt osv.)(min. зm.) \\
\hline Instruksjon - dialogisk & bruke/mobilisere elevenes kunnskap v/ innføring i fagstoff \\
\hline Spørsmål/svar & $\begin{array}{l}\text { systematisk bruk av sp./sv for å sjekke ut/ kontrollere elevenes } \\
\text { innsikt }\end{array}$ \\
\hline $\begin{array}{l}\text { Helklassesamtale/disku- } \\
\text { sjon }\end{array}$ & samtale der elevene kommenterer hverandres innspill \\
\hline Høytlesing & elevene leser høyt fra en lærebok eller annen tekst \\
\hline Elevframføring & elever framfører oppgaver/ dramatiseringer og tilsvarende \\
\hline Tilrettelegging & $\begin{array}{l}\text { lærer gir verbale/ikke verbale beskjeder om aktiviteter/ organise- } \\
\text { ring/ materialbruk }\end{array}$ \\
\hline Irettesetting & Iærer irettesetter elever/ grupper av elever \\
\hline Ikke faglig kommentarer & kommentarer av ikke faglig art \\
\hline \multicolumn{2}{|c|}{ Læreraktivitet ved individuelt arbeid } \\
\hline Individuell veiledning & lærer går rundt og gir hjelp/ støtte til enkeltelever \\
\hline \multicolumn{2}{|c|}{ Allmenngjøring av enkelt elever og /eller grupper av elevers spørsmål } \\
\hline Kollektiv veiledning & lærer veilederflere elever \\
\hline Går ut av rommet & lærerforlater undervisningsrommet \\
\hline Ikke interaksjon & lærer samhandler ikke med elevene; leser, rydder e.l. \\
\hline \multicolumn{2}{|c|}{ Læreraktivitet ved gruppearbeid } \\
\hline Individuell veiledning & lærer går rundt og gir hjelp/ støtte til enkeltelever \\
\hline Gruppe veiledning & lærer går rundt og gir hjelp/ støtte til grupper \\
\hline \multicolumn{2}{|c|}{ Allmenngjøring av grupper av elevers spørsmål } \\
\hline Ikke interaksjon & lærer samhandler ikke med elevene; leser, rydder e.l.) \\
\hline Går ut av rommet & lærer forlater undervisningsrommet \\
\hline
\end{tabular}

inn i flere underkoder, (se tabell 2, Klette et al. 2005). Kategorier og koder ble utviklet av PISA+ gruppen på basis av kategorier brukt i tidligere klasseromsstudier (f.eks. Klette, 2003; Alexander, 2000; Galton, Hargreaves, Comber, Wall, \& Pell, 1999) og våre data fra klasserommene.

Flere forskere var involvert i kodingen av timene. Reliabilitetstesten (ca. $10 \%$ av materialet) viste 75 - $89 \%$ overensstemmelse mellom de ulike koderne. Etter at undervisningsøktene ble kodet i Videograph, ble dataene overført til SPSS slik at man kunne sammenlikne og sammenfatte de ulike øktene. Kodingen som opprinnelig var oppgitt pr. sekund, ble nå transformert til minutter på den måten at den dominerende koden for hvert minutt ble gjort gjeldende. 
Tabell 3. Kodeskjema for naturfag (Ødegaard og Arnesen, 2006).

\begin{tabular}{|c|c|}
\hline \multicolumn{2}{|l|}{ Elevaktiviteter } \\
\hline Noterer (fra tavla etc.) & $\begin{array}{l}\text { Elevene skriver ned det som læreren skriver på tavlen, lysarket } \\
\text { e.l. }\end{array}$ \\
\hline Lese stille & Elevene leser stille fra tekstbok eller annen skriftlig kilde \\
\hline Praktisk arbeid & $\begin{array}{l}\text { Elevene driver en praktisk aktivitet; i klasserom, laboratorium, } \\
\text { ute }\end{array}$ \\
\hline Arbeide med oppgaver & $\begin{array}{l}\text { Elevene løser en oppgave individuelt eller i grupper. Oppgaven } \\
\text { kan være gitt av lærer eller fra arbeidsplanen }\end{array}$ \\
\hline Følger med aktivt eller passivt & $\begin{array}{l}\text { Elevene følger med på / er engasjert i en felles aktivitet i klas- } \\
\text { sen }\end{array}$ \\
\hline Bruk av IKT & $\begin{array}{l}\text { Elevene bruker IKT i læringen, dvs. at de sitter ved datamaski- } \\
\text { nen } \\
\text { Mer enn halve gruppa bruker IKT }\end{array}$ \\
\hline \multicolumn{2}{|l|}{ Tilbudte læringsaktiviteter } \\
\hline Aktivere tidligere kunnskap & $\begin{array}{l}\text { Relevant stoff fra tidligere timer eller elevenes egne oppfatnin- } \\
\text { ger mobiliseres med eller uten elevenes innspill }\end{array}$ \\
\hline Faglig appetittvekker & $\begin{array}{l}\text { Læreren gjør en demonstrasjon, viser frem konkreter eller } \\
\text { bruker en historie, vits, fortelling e.l. for å motivere interesse for } \\
\text { et tema }\end{array}$ \\
\hline Oppsummering av timen & $\begin{array}{l}\text { Timen oppsummeres gjennom monolog eller dialog med elev- } \\
\text { ene for å tydeliggjøre temaet så langt, eller for å oppsummere } \\
\text { hele timen mot slutten }\end{array}$ \\
\hline Gjennomgå arbeid fra timen & $\begin{array}{l}\text { Læreren går gjennom en aktivitet som har vært gjort i timen } \\
\text { enten ved å snakke selv eller gjennom dialog med elevene }\end{array}$ \\
\hline $\begin{array}{l}\text { Gjennomgå lekser eller annet } \\
\text { egenarbeid }\end{array}$ & $\begin{array}{l}\text { Læreren går gjennom leksenelegenarbeid enten ved å snakke } \\
\text { selv eller gjennom dialog med elevene }\end{array}$ \\
\hline Utvikle nytt fagstoff & $\begin{array}{l}\text { Læreren gjennomgår nytt stoff enten gjennom monolog, klas- } \\
\text { seromsdialog, elelr på annen måte }\end{array}$ \\
\hline Utvikle nye praktiske ferdigheter & $\begin{array}{l}\text { Læreren gjennomgår og følger opp nye ferdigheter knyttet til } \\
\text { praktiske aktiviteter }\end{array}$ \\
\hline \multicolumn{2}{|l|}{ Klasseromssamtale } \\
\hline Elevinitiativ & $\begin{array}{l}\text { Elevinitierte spørsmål eller kommentarer knyttet til faglig } \\
\text { innhold eller praktisk gjennomføring.Omfatter også svar og } \\
\text { kommenterer fra lærer/elever. Det kan gjerne være en serie } \\
\text { spørsmål }\end{array}$ \\
\hline Lærer snakker & $\begin{array}{l}\text { Læreren presenterer nytt materiale monologisk (ikke nød- } \\
\text { vendigvis av så lang varighet) eller forklarer noe nærmere i } \\
\text { forlengelsen av en respons til elevenes spørsmål. }\end{array}$ \\
\hline Lærerinitiativ & $\begin{array}{l}\text { Læreren stiller spørsmål, elevene besvarer for å mobilisere } \\
\text { elevenes kunnskaper og refleksjon. Læreren kan evaluere eller } \\
\text { kommentere svarene. Både spørsmål og kommentar kodes. }\end{array}$ \\
\hline
\end{tabular}




\section{Koding av naturfagtimene}

På grunnlag av felleskodingen, ble det utført ytterligere en koding på naturfagtimene. Hensikten var å analysere naturfaget i mer detalj for å si noe om hva som karakteriserer den pedagogiske flyten i timene. Felleskodingen indikerte at klasseromssamtalen er sentral i naturfagtimene. Derfor ble det lagt vekt på å karakterisere samtalen i klasserommet nærmere ved å kode hvorvidt det var lærer eller elever som tok initiativet. I tillegg ble elevaktiviteter og tilbudte aktiviteter fra lærer kodet. (se tabell 3) Kategoriene er utarbeidet med utgangspunkt i kategorier fra bl.a. "Talking Science" (Lemke 1990/2003) og "Meaning Making in Secondary Science Classrooms" (Mortimer \& Scott 2003). Kategorivalget er også påvirket av våre observasjoner. De ulike kategoriene, f.eks. tilbudte loeringsaktiviteter og klasseromssamtalen er her ikke gjensidig utelukkende, dvs. de forekommer og blir kodet samtidig, men kodene innenfor en kategori forekommer bare en om gangen. Analyser av språk- og begrepsbruken i PISA+ materiale vil presenteres i en kommende artikkel (Ødegaard \& Arnesen, in press).

\section{RESULtATER}

\section{Resultater fra felles koding for alle fag}

Fra felleskodingen ser vi at naturfag har en særegen profil med stor vekt på undervisning i hel klasse (figur 1). Figur 2 viser at helklasseundervisningen har stort innslag av dialogisk instruksjon. I tillegg ser at læreren bruk en god del tid på å tilrettelegge og organisere undervisningen for elevene. Andelen gruppebaserte aktiviteter er mindre enn forventet i de observerte klasserommene ut fra tidligere forskning om laboratoriearbeid som en sentral del av et naturfaglig undervisningsrepertoar, og L97s vektlegging av elevaktiviteter. Se også Klette et al. (2007). De læreraktiviteter som er mest fremtredende ved gruppearbeid, er gruppeveiledning og individuell veiledning. Likeledes under individuelt arbeid er individuell veiledning og veiledning av flere elever, mest fremtredende. Ved både gruppearbeid og individuelt arbeid er imidlertid allmenngjøring av elevers spørsmål, altså at lærer deler spørsmål som flere lurer på med hele klassen, så å si ikke forekommende. Resten av tiden er læreren ikke i interaksjon med elevene.

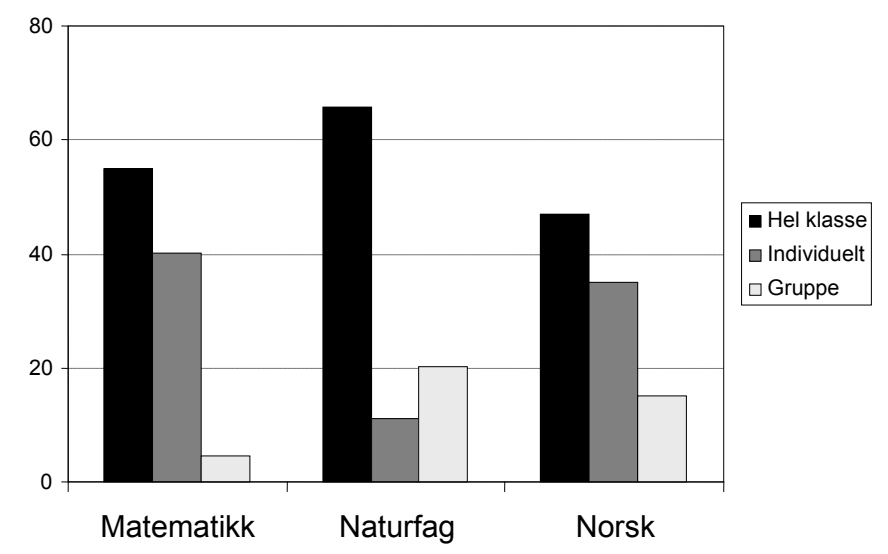

Figur 1. Hovedformer av instruksjonsformat i de ulike fagene i prosent av kodet tid. 


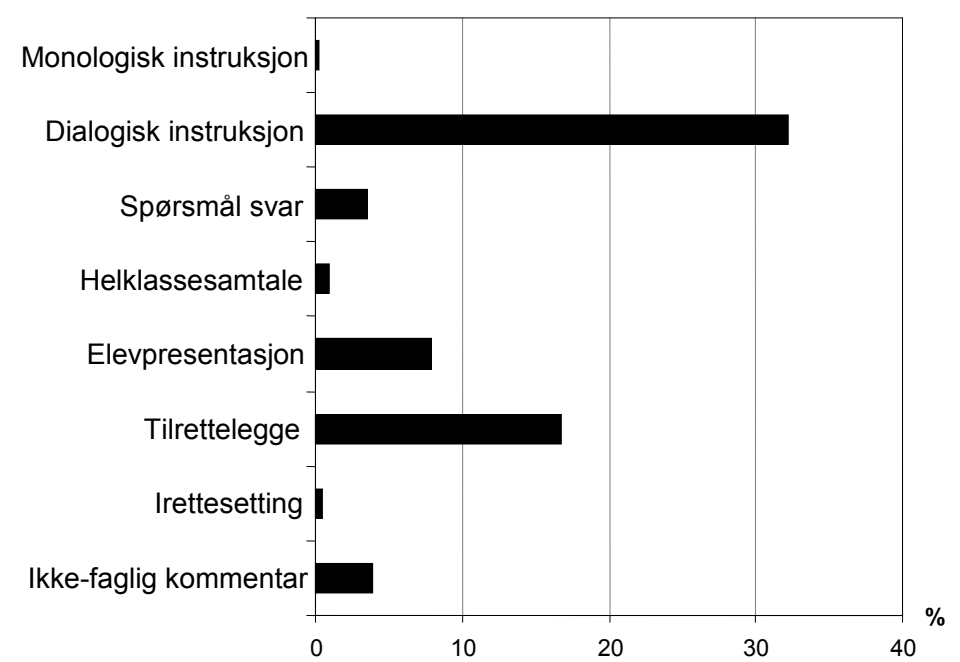

Figur 2. Fordeling på de ulike koder innenfor kategorien instruksjon i hel klasse i naturfag. Oppgis som prosent av kodet tid.

\section{Resultater fra kodingen av naturfag}

I det følgende blir resultatene fra kodingen av naturfagtimene kommentert. Det presiseres at analysene er foretatt ved å kategorisere observerbare hendelser og kvantifisere disse. Det er viktig å påpeke at lærerne som regel har gode begrunnelser for hver enkelt hendelse. Dette har vi data på gjennom observasjoner, samtaler og lærerintervju, men dette er ikke fokus for denne artikkelen (Se Ødegaard, 2008).

\section{Tilbudte læringsaktiviteter}

Vi ser av figur 3 at ved de observerte skolene blir det, som ventet, brukt mest tid på å utvikle nytt fagstoff. Dette kan innebære både teoretisk og praktisk kunnskap, holdningsarbeid i tema rusmidler, eller filosofiske og samfunnsmessige spørsmål i forbindelse med naturfag. Som nevnt under "resultater fra felles koding for alle fag" blir mye av tiden brukt til organisering og tilrettelegging av elevenes arbeid. Dette er den nest vanligste aktiviteten i naturfagtimene. Blant annet blir mye tid brukt på at lærer forteller elevene hvordan de skal arbeide med oppgaver, både skriftlige og praktiske; hva og hvor de skal skrive; hvem de skal samarbeide med osv. Både tilbudet om nytt fagstoff og tilrettelegging er sterkt lærerstyrt, men har en dialogisk form. Lærer inkluderer ofte elevenes initiativ under utviklingen av nytt fagstoff.

Praktisk arbeid forkommer i gjennomsnitt en tiendedel av tiden, noe som var lavere enn vi forventet i forhold til læreplanens (L97) store fokus på aktiviteter. I mange år har det vært tradisjon for å i en god del kommuner å sette av ekstra tid til delingstimer en gang i uka i naturfag for praktisk arbeid. Ingen av de observerte skolene gjorde systematisk bruk av delingstimer i naturfag. Av tabell 4 ser vi at praktisk arbeid kun forkommer på tre skoler. Dette kan delvis skyldes at emnene som ble undervist ikke alltid gjorde det naturlig å inkludere praktiske øvelser, for eksempel temaet rusmidler. Det må også nevnes at en av skolene hadde økologiekskursjon og en dag på en gård mens vi var der. Dette materialet var det imidlertid ikke mulig å dokumentere på en slik måte at vi har kunnet ta det med i de kvantitative analysene. Hvis vi imidlertid ser på hver av de skolene som hadde praktisk arbeid mens vi var tilstede, er det allikevel ikke en veldig stor del av undervisningstilbudet. 


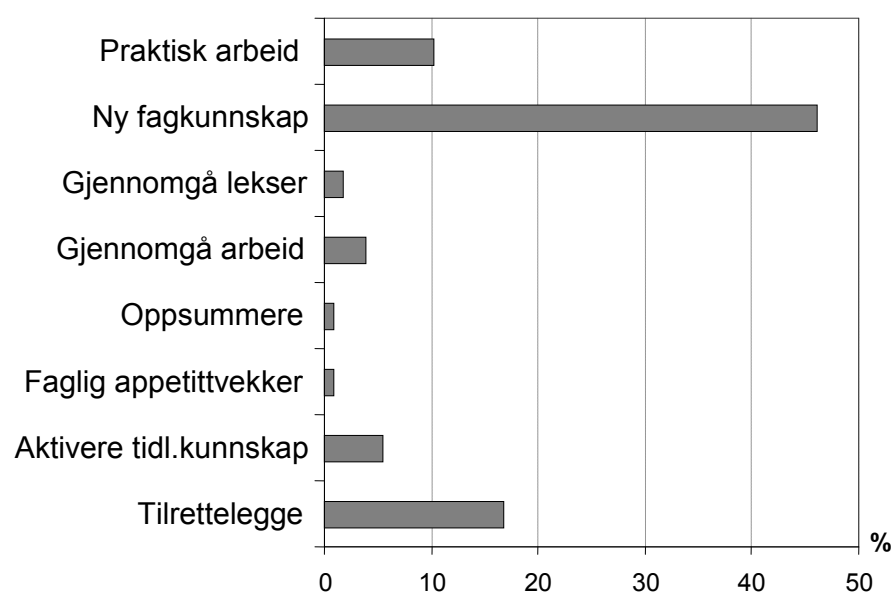

Figur 3. Her vises en oversikt over loerernes undervisningstilbud til elevene i prosent av kodet tid. (Ikke-faglig aktivitet er ikke tatt med. Tallene for koden tilrettelegge er overført fra felleskodingen til dette diagrammet.)

Didaktiske prinsipper som å gi en faglig appetittvekker og introduksjon til et emne og å foreta en oppsummering av timens faginnhold og aktiviteter forekommer sjelden. Å bruke dette som et fast organiserende prinsipp, blir sjelden gjennomført. Ved et par anledninger så vi at en faglig appetittvekker ble brukt som innledning til et nytt emne, og det skapte positivt elevengasjement. Ved en skole ble et nytt emne om kroppen introdusert ved en undrende filosofisk diskusjon om hvor vi kommer fra, og hvordan vi har utviklet oss. Dette ble diskutert med stor iver fra elevenes side. På en annen skole ble emnet fotosyntesen introdusert ved at læreren ga elevene et solsikkefrø og viste dem en høy solsikkeblomst og ba elevene tenke over hvordan frøet kunne bli så stort.

Et annet naturfagdidaktisk prinsipp er å aktivisere tidligere kjent kunnskap. Dessuten vektlegges betydningen av å sammenlikne egne forestillinger med andres og se dem i sammenheng med naturvitenskapens forklaringer. I vårt materiale har vi kodet dette som aktivisere tidligere kunnskap. Koden forekommer en del, men stort sett er den en kort spørsmål-svar sekvens i hel klasse styrt av lærer. Ved kun ett tilfelle la læreren opp til at elevene skulle diskutere med hverandre hva de kunne om et emne fra før på generelt grunnlag. ("Hva husker dere om fotosyntesen?")

Vi så sjelden gjennomgang av arbeid fra timen, se figur 3 . Vi har observert at elever får ulike typer arbeid de skal gjøre på egen hånd eller sammen med andre i undervisningsøkten. Det kan være oppgaver fra boka eller lærer, skrive lab-rapport, skrive evaluering av gårdsbesøk, forberede foredrag eller liknende. De få gangene det forekommer gjennomgang av dette arbeidet i den aktuelle timen har elevene jobbet med en konkret avgrenset oppgave i undervisningsøkten. Heller ikke når elevene skriver lab-rapporter, blir arbeidet gjennomgått. Vi observerte ikke at det ble gitt eller gjennomgått hjemmearbeid.

I tabell 4 ser vi variasjon i analysene for hver skole for kategorien tilbudte aktiviteter. Vi ser at felles for alle skolene er at gjennomgang av nytt fagstoff er en dominerende aktivitet sammen med tilrettelegging. For skole 1 gjelder bare én time. 
Tabell 4. Variasjon i laereres tilbud om loeringsaktiviteter ved de ulike skoler som inngår $i$ studien. Tallene er prosent av kodet tid på hver skole.

\begin{tabular}{|c|c|c|c|c|c|c|c|c|c|}
\hline Skole & $\begin{array}{l}\text { Til- } \\
\text { rette- } \\
\text { legge }\end{array}$ & $\begin{array}{l}\text { Aktiver } \\
\text { tidligere } \\
\text { kunn- } \\
\text { skap }\end{array}$ & $\begin{array}{l}\text { Faglig } \\
\text { appetitt- } \\
\text { vekker }\end{array}$ & $\begin{array}{l}\text { Opp- } \\
\text { sum- } \\
\text { mere }\end{array}$ & $\begin{array}{l}\text { Gjennom- } \\
\text { gå arbeid }\end{array}$ & $\begin{array}{l}\text { Gjennom- } \\
\text { gå lekser }\end{array}$ & $\begin{array}{l}\text { Ny fag- } \\
\text { kunnskap }\end{array}$ & $\begin{array}{l}\text { Praktisk } \\
\text { arbeid }\end{array}$ & Annet \\
\hline 1 & 12,6 & 2,4 & 14,6 & 0 & 9,8 & 0 & 60,6 & 0 & 0 \\
\hline 2 & 8,5 & 11,9 & 0,2 & 0 & 6,7 & 9,7 & 57,7 & 0 & 5,3 \\
\hline 3 & 23,9 & 4,9 & 0,5 & 4,7 & 0 & 0 & 30,1 & 13,8 & 22,1 \\
\hline 4 & 24,1 & 11,2 & 0 & 0 & 2,9 & 0 & 37,9 & 0 & 23,9 \\
\hline 5 & 15,4 & 3,1 & 0,8 & 0,1 & 3,9 & 0 & 51,3 & 15,8 & 9,6 \\
\hline 6 & 15,8 & 0 & 1,6 & 0 & 5,3 & 0 & 45,1 & 13 & 19,2 \\
\hline
\end{tabular}

\section{Elevaktiviteter}

Av figur 4 ser vi at den dominerende aktiviteten er at elevene følger med enten passivt eller aktivt; ved å svare på spørsmål, kommentere det som blir gjennomgått eller notere fra tavla. Dette gjelder for alle involverte skoler. Den nest største aktiviteten er at elevene arbeider med ulike typer oppgaver som ofte skal besvares skriftlig; enten ved å svare på spørsmål, skrive rapporter eller samle informasjon fra f.eks. bibliotek og internett. Koden bruker IKT blir brukt i de tilfeller hvor mer enn $50 \%$ av klassen/gruppa har det som felles aktivitet. Dette skjer på tre skoler, hvorav en klasse jobber med en egen side utviklet av læreren på den lokale læringsplattformen (LMS) og to bruker Viten.no som er en nettbasert læringsplattform utviklet ved UiO og NTNU, http://viten.no.

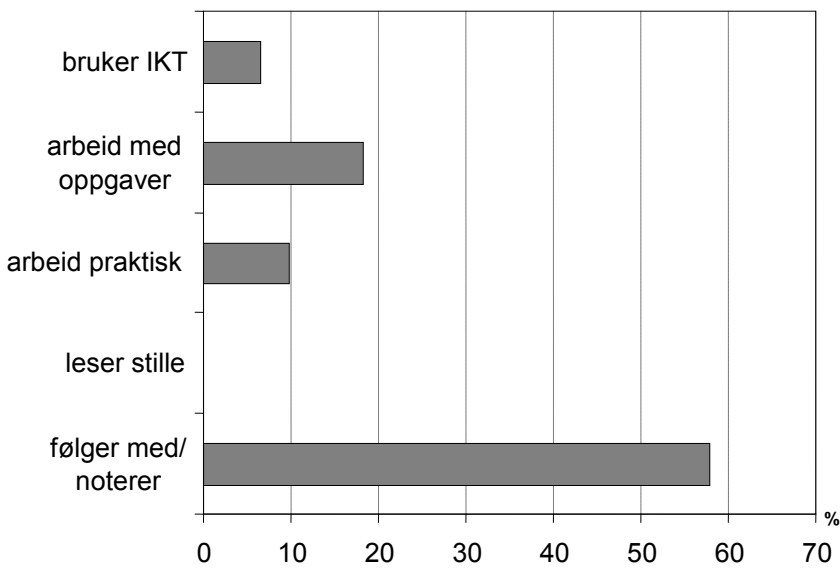

Figur 4. Her vises en oversikt over elevenes loeringsaktiviteter i prosent av kodet tid.

\section{Klasseromssamtalen}

Samtalen som foregår i hel klasse mellom lærer og elever eller elever imellom, har vi kalt for klasseromssamtale. Vi har skilt mellom når læreren snakker, altså hvor hele klassen har fokus på det læreren sier, og når læreren tar et initiativ til dialog med elevene enten ved å stille spørsmål, invitere til diskusjon eller liknende. Her kodes både lærerens initiativ og elevenes svar som loererinitiativ. Elevinitiativ er når det er elevene selv som tar initiativet til å drive samtalen, ved f.eks. å stille faglig spørsmål, eller komme med nye kommentarer eller argumenter som gjør at klassesamtalen tar en ny retning. Både elevens spørsmål og lærerens svar kodes som elevinitiativ (se tabell 3). 
Tabell 5. Ulike typer elevinitiativ med eksempler fra én undervisningsøkt i naturfag.

\begin{tabular}{lc}
\hline Elevinitiativ fra en undervisnings $\varnothing \mathbf{k t} \Sigma=\mathbf{2 6}$ & $\begin{array}{c}\text { Antall hen- } \\
\text { delser: }\end{array}$ \\
\hline $\begin{array}{l}\text { Om tavlebruk / notater: } \\
\text { "Skal vi skrive det i boka vår?" }\end{array}$ & 9 \\
$\begin{array}{l}\text { Om praktiske spørsmål / organisering: } \\
\text { "Hvem skal være i den gruppa?" }\end{array}$ & 7 \\
$\begin{array}{l}\text { Om praktisk arbeid: } \\
\text { "Hva skal vi gjøre egentlig?" }\end{array}$ & 3 \\
$\begin{array}{l}\text { Faglige kommentarer: } \\
\text { Skal det ikke være hydrogen, ikke nitrogen?” } \\
\begin{array}{l}\text { Om å skape mening: } \\
\text { ler dette om fotosyntese?" }\end{array}\end{array}$ \\
\hline
\end{tabular}

Koden laerer snakker gjelder i ca. en tredjedel av tiden, mens laererinitiativ og elevinitiativ begge kodes i ca. en sjettedel av undervisningstiden, dvs. at både lærer og elever påvirker dialogdelen av klassesamtalen.

Som et eksempel har vi tatt for oss én undervisningsøkt og undersøkt nærmere hva elevinitiativene består av. Undervisningsøkten som her er valgt ut og analysert er en forholdsvis strukturert naturfagtime om fotosyntese med både teori og praktisk arbeid. Vi fant at sekvensene med elevinitiativ i hovedsak er knyttet til spørsmål om hvordan elevene skal utføre ulike oppgaver og handlinger, se tabell 5. Tabellen viser også at noen elevinitiativer er knyttet til det faglige innholdet i timen. Nærmere forskning omkring slike situasjoner vil gi oss mer informasjon om betydningen av dette initiativmønsteret. For eksempel, hvordan responderer lærere på de ulike elevinitiativene? Hvor mye naturfag bringes inn i praktiske spørsmål? Vi håper siden å få fram et samlet bilde av hvordan elevinitierte spørsmål kan påvirke undervisningen i naturfag.

\section{DisKuSJON}

\section{Læringsaktiviteter}

Fellesanalysene for alle de tre fagene viste at naturfaget har et høyt innslag av helklasseundervisning sammenlignet med de to andre fagene. Dette betyr imidlertid ikke at læreren står og snakker hele tiden. Analysen av klasseromssamtalen viser at en stor del av den samtalen som foregår ved helklasseundervisning, er initiert av elever. Lærere er inkluderende og gir plass til elevenes kommentarer og spørsmål i undervisningen. Dette stemmer overens med det som ble rapportert i evalueringsstudien av Reform 97 (Klette, 2003). Anderson (2007) viser til viktigheten av at elever bidrar med autentiske spørsmål og medvirker til å løse felles problemer. Engle og Conant (2002) understreker betydningen av at elevene problematiserer det faglige innholdet ved å stille spørsmål og ved å være reelle bidragsytere. At det er et klima for å inkludere elevenes egne spørsmål og kommentarer gir et godt utgangspunkt for en meningsskapende naturfagundervisning. I vår studie er elevenes utspill ikke knyttet til det faglige innholdet i stor grad, men vi vet ikke nok om dette. Vi har sett eksempler på at elevinitiativer er knyttet både til praktiske og noe faglige spørsmål, og mest knyttet til beskrivelser. Ut fra dette mener vi at det er en utfordring for norske naturfaglærere å motivere og legge til rette for at elever skal beskjeftige seg mer med "hvorfor"-spørsmål. For å få mer kunnskap om elevenes påvirkning på den pedagogiske flyten og meningsskaping i naturfag, kreves mer detaljerte studier. 
I figur 3 så vi at det var lite fokus på oppsummering og på å gjennomgå elevenes egenarbeid. Likevel viser figur 4 at elevene bruker en del tid på å arbeide med oppgaver. Hvorfor blir ikke dette arbeidet oppsummert eller gjennomgått? For å finne mer ut om dette så vi nærmere på de undervisningsøktene hvor vi faktisk hadde både gjennomgåelse av arbeid og arbeide med oppgaver. Det viste seg at i disse timene gjorde elevene oppgaver som var nært knyttet til dagens gjennomgåtte tema. Det var enten oppgaver læreren hadde laget eller oppgaver fra boka. Det som kjennetegnet det arbeidet elevene gjorde og som ikke ble gjennomgått eller oppsummert i samme time, var at det var knyttet til oppgaver som skulle evalueres senere; enten i tilknytning til prosjektarbeid, arbeidsplan eller labrapporter. Felles for alle disse læringsaktivitetene er at elevene får en forsinket tilbakemelding på sitt eget arbeid. Dette er ikke noe nytt når det gjelder lab-rapporter, men omfanget av prosjektarbeid og bruk av arbeidsplan har økt i de siste årene. Dette er arbeidsformer som krever stor grad av elevautonomi, og som ble innført delvis på grunn av påtrykk fra læreplanen (L97), og delvis for å møte utfordringene med individuelt tilpasset opplæring. Dette stemmer overens med refleksjoner gjort av Klette et al. (2003), Schmidt et al. (1996) og Kjærnsli et al. (2004, 2007). Vi ser at innføring av et arbeidsredskap for å løse en utfordring, kan skape nye utilsiktede problem. Arbeidsplanen som blant annet ble innført for å møte utfordringen om ansvar for egen læring og tilpasset opplæring, fører til at elevene får utsatt tilbakemelding på sine arbeider og dermed et lavt læringstrykk (Bergem, 2007). Nye arbeidsformer førte antagelig også til mangel på funn av koden gjennomgå hjemmearbeid, fordi elevene ikke lenger får det som tradisjonelt er kalt "lekser".

Vi fant at mindre tid enn forventet ble brukt på praktisk arbeid på våre studieskoler. Dette skyldes delvis tilfeldigheter som sykdom eller undervisningstema. Som nevnt, hadde ingen av de observerte skolene faste delingstimer knyttet til elevøvelser i naturfag, så gruppene som håndterte det praktiske utstyret, ble store. Dermed ble situasjonen fort uoversiktlig, og læreren brukte mye tid på å organisere gruppene og motivere enkeltelever til å gjøre noe. Det er kanskje et paradoks at læreren bruker mye mer tid på å fortelle elevene hva de skal gjøre (tilrettelegge) enn å gi elevene tid til egne aktiviteter?

Vi så lite systematisk bruk av de praktiske øvelsene som innfallsvinkel for faglig diskusjon hvor man knytter sammen teori og praksis i en utprøvende muntlig dialog. Dette støttes av funnet om lite bruk av empiriske referanser. Således går man glipp av noen gylne sjanser til å utnytte elevenes praktiske fagengasjement og samhandling til intellektuell framgang slik Engle og Conant (2002) beskriver det. Kan det være at i en stresset skolehverdag med høyt press på "å komme gjennom pensum" at det kan gå litt på akkord med praktisk arbeid, særlig hvis man ser det som et tillegg til og ikke et bidrag til det teoretiske pensumet?

\section{KONKLUSJON/AVSLUTTENDE KOMMENTAR}

Undervisning og læring i naturfag er komplekse prosesser. I en omfattende videostudie som denne må man gjøre et utvalg i forhold til hva man vil fokusere på. De kategorier og skalaer man velger til sine analyser, vil påvirke det bildet man gir. Dette diskuteres i en egen metode-artikkel (Ødegaard \& Klette, in press).

I denne artikkelen har vi valgt å fokusere på hvilke læringsaktiviteter elevene får tilbud om, i hvilken grad elevene er med og påvirker sin egen undervisning og i hvilken grad det tilrettelegges for at elever skal tilegne seg naturfaglig kunnskap basert på egne erfaringer og bruk av samtale.

For å oppsummere våre data kan vi si at de vanligste læringsaktivitetene i naturfagklasserommene vi besøkte var innføring av nytt fagstoff gjennom bruk av klasseromsdialog eller arbeid med oppgaver.Vi så lite varierte arbeids- og organiseringsmønstre, noe som er i tråd med tidligere funn (Klette, 2003; Schmidt et al., 1996) Praktisk arbeid er fortsatt sentralt, men det forekommer mye mindre enn vi hadde forventet (jfr. Almendingen, Klepaker, \& Tveita, 2003). Elevenes arbeid er 
ofte knyttet til arbeidsformer som gjennomgåes og oppsummeres senere i undervisningsforløpet, f.eks. prosjektarbeid, arbeidsoppgaver på en arbeidsplan og elevøvelsesrapporter. Dette er ikke heldig ut fra didaktiske prinsipper om gjentagelse, jevnt læringstrykk og regelmessig tilbakemelding. Det kan se ut til at nye læringsaktiviteter som prosjektarbeid og bruk av arbeidsplaner har fått noen utilsiktede konsekvenser.

Lærerne er svært lydhøre for elevenes initiativ og inkluderer dem i undervisningen. Elevenes mening er viktig. Vi kan dermed si at elevene er med og påvirker sin egen naturfagundervisning. Vi kan allikevel ikke si at vår studie viser at elevene har en stor faglig påvirkning (se tabell 5). Imidlertid har den inkluderende atmosfæren i klasserommene potensiale i seg til å også omfatte aktiviteter med mer faglig elevmedvirkning (jfr. Anderson, 2007; Engle \& Conant, 2002).

I vår studie så vi noe praktisk arbeidet, men det ble ikke brukt systematisk som samtalearena. Vi så heller ikke ellers mange gode fagsentrerte samtaler mellom elever hvor elever brukte egne erfaringer og språket for å oppnå faglig forståelse, eller faglige samtaler med lærer som hjelper til å skape bro mellom praksis og teori, slik vi har beskrevet over (Mortimer \& Scott, 2003; Scott, Asoko \& Leach, 2007; Wellington \& Osborne, 2001).

Vi forventet ikke å kunne gi et klart svar på hvorfor prestasjonsnivået i naturfag har gått ned, men vi håper at våre studier bidrar til at vi ser på det som skjer i naturfagklasserommet på en litt ny måte. Ved å kvantifisere observasjoner trer andre mønstre fram enn de vi er vant til å se etter, for eksempel graden av beskrivelser i forhold til forklaringer. Vi håper på denne måten til å medvirke til at lærere og andre skolefolk engasjeres i en faglig debatt om norsk naturfagundervisning.

\section{REFERANSER}

Alexander, R. (2000). Culture \& Pedagogy. Malden: Blackwell Publishing.

Almendingen, S., Klepaker, T. \& Tveita, J. (2003). Tenke det, ønske det, ville det med, men gjøre det...? En evaluering av natur- og miljøfag etter Reform 97. Nesna: skriftserien til Høgskolen i Nesna, nr 52.

Anderson, R.D. (2007). Inquiry as an Organizing Theme for Science Curricula. I S. K. Abell \& N. G. Lederman (Red.), Handbook of Research on Science Education (s. 807-830). Kentucky: Lawrence Erlbaum Associates.

Bergem, O.K. (2007). Workplans in Mathematics - a Valuable Tool or a Risky Experiment? Paper presented at EARLI biennial conference 28. August - 1. September, Budapest, Hungary.

Carlsen, W. S. (2007). Language and science learning. I S. K. Abell \& N. G. Lederman (Red.), Handbook of Research on Science Education (s. 57-74) Kentucky: Lawrence Erlbaum Associates.

Clark, D. (2002). The Learner's Perspective Study: Methodology as the Enactment of a Theory of Practice. Paper presented at the interactive symposium 'International Perspectives on Mathematics Classrooms' at the Annual Meeting of the American Educational Research Association, New Orleans, April, 2002. http://extranet.edfac.unimelb.edu.au/DSME/lps/assets/ AERA_Clarke_Method.pdf

Dewey, J. (1936). The theory of the Chicago Experiment. I K.C. Mayhew \& A.C. Edwards (Red.), The Dewey School: The Laboratory School of the University of Chicago, 1896-1903 (s.463466). New York: Appelton-Century

Driver, R. (1983). The Pupil as Scientist? Milton Keynes: Open University Press

Engle, R.A. \& Conant, F.R. (2002). Guiding principles for fostering productive

disciplinary engagement: Explaining an emergent argument in a community of learner's

classroom. Cognition and Instruction, 20, 399-484.

Galton, M., Hargreaves, L., Comber, C., Wall, D \& Pell, A. (1999). Inside the Primary Classroom: 20 years On. London: Routledge. 
Grønmo, L.S., Bergem, O.K., Kjærnsli, M., Lie, S. \& Turmo, A. (2004). Hva i all verden har skjedd $i$ realfagene? Norske elevers prestasjoner $i$ matematikk og naturfag i TIMSS 2003. Oslo, Universitetet i Oslo.

Grønmo, L. S. \& Onstad, T. (2008). TIMSS 2007: Tegn til bedring? Oslo: Unipub.

Isnes, A. (2005). Kunnskapsløftet og nye utfordringer i naturfag. Naturfag 3, 4-6.

Jenkins, E. W. (1999). Practical Work in School Science - some questions to be answered. I J. Leach \& A.C. Paulsen (Red.), Practical Work in Science Education. Recent Research Studies. (s. 17-32). Fredriksberg: Roskilde University Press

Keys, C.W. \& Bryan, L.A. (2001). Co-constructing inquiry-based science with teachers: Essential research for lasting reform. Journal of Research in Science Teaching. 38(6), 631-645.

Kind, P.M., Kjærnsli, M, Lie, S. \& Turmo, A. (1999). Hva i all verden gjør elevene i realfag? Praktiske oppgaver i matematikk og naturfag. Oslo: Institutt for lærerutdanning og skoleutvikling, Universitet i Oslo.

Kirke-, utdannings- og forskningsdepartementet (KUF) (1996). Laereplanverket for den 10-årige grunnskolen. Oslo: Nasjonalt læremiddelsenter.

Kjærnsli, M., Lie, S., Olsen, R.V., Roe, A. \& Turmo, A. (2004). Rett spor eller ville veier? Norske elevers prestasjoner i matematikk, naturfag og lesing i PISA 2003. Oslo: Universitetsforlaget.

Kjærnsli, M., Lie, S., Olsen, R.V. \& Roe, A. (2007). Tid for tunge løft. Norske elevers kompetanse $i$ naturfag, lesing og matematikk i PISA 2006. Oslo: Universitetsforlaget.

Klepaker, T., Almendingen, S. F. \& Tveita, J. (2007). Young Norwegian students' preferences for learning activities and the influence of these activities on the students' attitudes to and performance in science. NorDiNa, 3(1), 45-56.

Klette, K. (2003). Lærernes klasseromsarbeid: Interaksjons- og arbeidsformer i norske klasserom etter Reform 97. I: Klette, K. (red) Klasserommets praksisformer etter Reform 97 (s. 39-77). Oslo: Unipub.

Klette, K., Lie, S., Anmarkrud, Ø., Arnesen, N., Bergem, O.K., Ødegaard, M. et al.., (2005). Categories for video analysis of classroom activities with a focus on the teacher. Oslo: University of Oslo.

Klette K., Lie, S., Ødegaard, M., Anmarkrud, Ø., Arnesen, N.E., Bergem, O.K. et al. (2007). Rapport om forskningsprosjektet PISA+. Oslo: Norges Forskningsråd.

Kunnskapsdepartementet (KD) (2006). Loereplanverket for Kunnskapsløftet. Oslo: Utdanningsdirektoratet.

Leach, J. \& Scott, P. (2003). Individual and Sociocultural Views on Learning in Science Education. Science \& Education 12, 91-113.

Lemke, J. (1990, nytt opptrykk 2003). Talking Science. Language, learning and values. Norwood, NJ: Ablex Publishing.

Lemke, J. (2001). Articulating communities: Sociocultural perspectives on science education. Journal of Research in Science Teaching, 38 (3), 296 - 316.

Lie, S., Kjærnsli, M., Roe, A. \& Turmo, A. (2001). Godt rustet for framtida? Norske 15-åringers kompetanse $i$ lesing og realfag $i$ et internasjonalt perspektiv. Oslo: Institutt for lærerutdanning og skoleutvikling, Universitetet i Oslo.

Mortimer, E. \& Scott, P. (2003). Meaning Making in Secondary Science Classrooms. Maidenhead: Open University Press.

Rimmele, R. (2002). Videograph. Multimedia-Player zur Kodierung von Videos. Kiel: IPN.

Schmidt, W., Jorde, D., Cogan, L.S., Barrier, E., Gonzalo, I., Moser, U. et al. (1996). Characterizing Pedagogical Flow. Dordrecht: Kluwer Academic Publishers.

Scott, P., Asoko, H., \& Leach, J. (2007). Student Conceptions and Conceptual Learning in Science. I S. K. Abell \& N. G. Lederman (Red.) Handbook of Research on Science Education (s. 3156). Kentucky: Lawrence Erlbaum Associates.

Sjøberg, S. (2004) Naturfag som allmenndannelse - en kritisk fagdidaktikk. Oslo: Gyldendal akademisk.

Vygotsky, L. S. (1978). Mind in Society. Cambridge, Massachusetts: Harvard University Press. 
Vygotsky, L. S. (1934/1986). Thought and Language. Cambridge, Mass.: MIT press.

Wellington, J. \& Osborne, J. (2001). Language and Literacy in Science Education. Buckingham Open University Press.

Ødegaard, M. (2008) Love and Duty in Science Education - Teacher Commitments-a classroom video study. I M.V. Polaki, T. Mokuku \& T. Nyabanyaba (Red..) Proceedings of the $16^{\text {th }}$ annual conference of the Southern African Association for research in Mathematics, Science and Technology Education, SAARMSTE 2008. 14.-18. January 2008, Maseru, Lesotho.

Ødegaard, M. \& Arnesen, N.E. (2006). Categories for video analysis of science classroom activities. Oslo: University of Oslo.

Ødegaard, M. \& Arnesen, N. E. (in press). Samtale og språkbruk i naturfagklasserommet. - resultater fra en videobasert klasseromsstudie; PISA+

Ødegaard, M. \& Klette, K. (in press). Teaching Activities and Language Use in Science Classrooms: Scales and Analytical Categories as Pillars for Possible interpretations. 